\title{
Studies on the availability of iron in potatoes
}

\author{
BY SUSAN J. FAIR WEATHER-TAIT \\ ARC Food Research Institute, Colney Lane, Norwich NR4 7UA
}

(Received 22 October 1982 - Accepted 24 January 1983)

1. Iron availability in potatoes and ferrous sulphate was measured in rats in a $\mathbf{1 0} \mathrm{d}$ balance study and from a single meal using ${ }^{59} \mathrm{Fe}$ and ${ }^{55} \mathrm{Fe}$ as extrinsic labels.

2. Dried potato samples were incubated in gastric juice in vitro and the amount solubilized was compared with other foods. The relationship between ascorbic acid content of dried potato and Fe solubilization was examined in vitro.

3. In the balance study, the rats absorbed (mean with $\mathrm{SE}$ ) $15.2(2.7) \% \mathrm{Fe}$ from the diet containing $660 \mathrm{~g}$ dried potato $/ \mathrm{kg}$ and $32.1(2.8) \%$ Fe from the semi-synthetic diet containing FeSO $\mathrm{F}_{4}$. Absorption was higher from the extrinsically-labelled single meal: $49 \cdot 6(1 \cdot 1) \% \mathrm{Fe}$ from ${ }^{59} \mathrm{Fe}$-labelled potato and $62 \cdot 4(1 \cdot 2) \% \mathrm{Fe}^{\circ}$ from $^{59} \mathrm{FeSO}_{4}$.

4. The in vitro experiments showed a much greater solubilization of Fe from potato than from the other foods examined. There was a correlation between Fe solubilization and ascorbic acid content of potatoes $\left(r_{s} 0.76\right.$, $P<0.01$ ).

5. It appears that potatoes contain Fe of moderate availability, possibly higher than most vegetables. They also provide ascorbic acid which may enhance $\mathrm{Fe}$ absorption from a meal if present in sufficient quantities. Thus potatoes may make a useful contribution towards the Fe nutriture of the UK population.

The amount of iron contributed by potatoes (Solanum tuberosum) to the average UK daily diet is $6.2 \%$ (Ministry of Agriculture, Fisheries and Food, 1980) which is more than any other single vegetable. Main-crop potatoes contain approximately $3 \mathrm{mg} \mathrm{Fe} / \mathrm{kg}$ and new potatoes $4 \mathrm{mg} \mathrm{Fe} / \mathrm{kg}$ (Paul \& Southgate, 1978) which is lower than most green vegetables, e.g. Savoy cabbage (var., Brassica oleracea) $7 \mathrm{mg} \mathrm{Fe} / \mathrm{kg}$ and Brussels sprouts (var., Brassica oleracea) $5 \mathrm{mg} \mathrm{Fe} / \mathrm{kg}$. However, potatoes are consumed daily and usually in larger quantities than other vegetables. Indeed, people from low-income groups, particularly families with several children consume greater amounts of potato than the national average. Thus potatoes make a small but measurable contribution towards Fe intake and, after liver, bread and canned beans, they are considered good nutritional value for money, contributing $0.3 \mathrm{mg} \mathrm{Fe} /$ penny (Ministry of Agriculture, Fisheries and Food, 1980).

Since only approximately $10 \%$ of total dietary $\mathrm{Fe}$ is absorbed, absolute values for $\mathrm{Fe}$ intake are meaningless unless accompanied by some indication of availability. The limited number of reports in the literature suggest that the availability of $\mathrm{Fe}$ in vegetables is low. For example, Layrisse et al. (1969) found that $\mathrm{Fe}$ absorption from spinach (Spinacea oleracea) by human subjects was $1.7 \%$, from black beans (Phaseolus vulgaris) $3.2 \%$ and from lettuce (Lactuca sativa) plus tomato juice $5 \cdot 8 \%$. In comparison, Fe from meat and fish was better absorbed with meat values ranging from 16 to $20 \%$. In order to standardize the results and make them comparable with other studies, ferrous ascorbate absorption was also measured in each individual. The food Fe:ferrous ascorbate values were 0.11 for spinach, 0.17 for black beans, 0.31 for lettuce, 0.4 for fish and 1.31 for veal. There is, however, no information to date on the availability of $\mathrm{Fe}$ in potatoes.

In any meal haem- and non-haem-Fe enter two separate pools which are absorbed by different pathways: non-haem-Fe is generally less well-absorbed than haem-Fe but absorption can be improved in the presence of certain substances such as ascorbic acid. Potatoes contain significant levels of ascorbic acid ( $40-140 \mathrm{mg} / \mathrm{kg})$, the actual amount being dependent on the maturity of the tuber, length of storage and the type of cooking. It is, 
therefore, quite possible that the $\mathrm{Fe}$ in potatoes when consumed alone is reasonably well-absorbed, and that when potatoes are eaten with a meal the ascorbic acid present will enhance Fe absorption from the non-haem pool.

Rats appear to absorb non-haem-Fe as well as or better than haem-Fe (Amine \& Hegsted, 1971) which is different from man. They are, therefore, considered to be of limited use in Fe absorption studies involving haem-Fe but, because of the problems inherent in using radiotracers to measure $\mathrm{Fe}$ absorption in man accurately, they are still frequently used in studies of non-haem-Fe absorption. Indeed, the Association of Official Analytical Chemists' method for measuring bioavailability of $\mathrm{Fe}$ uses the technique of haemoglobin repletion in anaemic rats (Fritz et al. 1974). In the present study, Fe availability in potatoes and ferrous sulphate was measured in rats by the conventional balance technique and by using extrinsic radio-labels.

Recent work has shown good agreement between in vivo and in vitro methods for determining the availability of $\mathrm{Fe}$ in foods (Schricker et al. 1981). Dried samples of potato were therefore incubated in gastric juice in vitro by the method of Lock \& Bender (1980) and the amount of Fe solubilized was compared with other foods. The relationship between ascorbic acid and $\mathrm{Fe}$ solubilization was examined in vitro.

\section{MATERIALS AND METHODS \\ Animal experiments}

Diets. Main-crop potatoes (var. Maris Piper) were baked in their skins in a microwave oven. The skins were peeled off and the potato was mashed, freeze-dried and then ground to a powder in a Moulinex coffee-grinder with tungsten-carbide blades and analysed for ascorbic acid. For the balance experiment the dried potato was incorporated into a semi-synthetic diet with the following composition $(\mathrm{g} / \mathrm{kg})$ : dried potato 660 , casein 200 , maize oil 80 , mineral mix 40 , vitamin mix 20 . The control diet in which the main source of Fe was ferrous sulphate contained $(\mathrm{g} / \mathrm{kg}$ ) maize starch 315 , sucrose 315 , casein 230 , maize oil 80 , mineral mix 40 , vitamin mix 20 . The mineral mix contained $(\mathrm{g} / \mathrm{kg}$ diet): calcium hydrogen phosphate $13 \cdot 0$, calcium carbonate $8 \cdot 2$, potassium chloride $7 \cdot 03$, disodium hydrogen phosphate $7 \cdot 4$, magnesium sulphate $4 \cdot 0$, manganese sulphate $0 \cdot 18$, zinc carbonate $0 \cdot 10$, copper sulphate $0 \cdot 015$, potassium iodate $0 \cdot 001 . \mathrm{FeSO}_{4}$ was added to the control diet to bring the $\mathrm{Fe}$ level up to that of the potato diet. The vitamin mix contained $(\mathrm{mg} / \mathrm{kg}$ diet): nicotinic acid 60 , cyanocobalamin in mannitol 50, calcium D-pantothenate 40 , thiamin hydrochloride 10 , riboflavin 10 , pyridoxine 10 , pteroylmonoglutamic acid 5 , D-biotin 1 , menadione 1, Rovimix E-25 (Roche) 300, Rovimix A-500 (Roche) 25, Rovimix A-500/D3 (Roche) 15, choline bitartrate 1800 .

\section{Balance experiment}

Twenty weanling male Wistar rats (mean weight $70 \mathrm{~g}$ ) were randomly allocated to two groups of ten each and given the control semi-synthetic diet for $2 \mathrm{~d}$. One group was then given the diet containing potato, the main source of $\mathrm{Fe}$, whilst the other remained on the control diet where the $\mathrm{Fe}$ was derived from added $\mathrm{FeSO}_{4}$. Food intakes were measured and faecal collections made for $10 \mathrm{~d}$. Diets and faeces were analysed for $\mathrm{Fe}$ and absorption calculated.

\section{Radioisotope experiment}

Twenty-six weanling male Wistar rats (mean weight $80 \mathrm{~g}$ ) were divided into two groups of thirteen each and trained to meal-feed on the semi-synthetic control diet. After 1 week, following an overnight fast (day 1), group 1 was given a meal of $3 \mathrm{~g}$ dried potato (containing $79 \mu \mathrm{g} \mathrm{Fe}$ ) mixed to a paste with $10 \mathrm{ml}$ distilled water and group 2 was given $12 \mathrm{~g}$ starch- 
sucrose (50:50,w/w) paste (containing $52 \mu \mathrm{g} \mathrm{Fe}$ as $\mathrm{FeSO}_{4}$ ). Both meals were extrinsically labelled with $5 \mu \mathrm{Ci}{ }^{59} \mathrm{Fe}$ (ferric chloride in $0.1 \mathrm{M}$-hydrochloric acid; Amersham International, Amersham, Bucks.). The following day (day 2) they were given the control diet. On day 3 the procedure was repeated, except that group 1 received $\mathrm{FeSO}_{4}$ and group 2 potato. The meals were labelled with $12 \mu \mathrm{Ci}{ }^{55} \mathrm{Fe}$ (carrier-free; Amersham International). The following day they were returned to the control diet. Daily faecal collections were carried out from day 1 onwards for $12 \mathrm{~d}$ and the ${ }^{59} \mathrm{Fe}$ content counted in a gamma-counter. On day 12 the animals were weighed and killed. Blood was removed by cardiac puncture whilst the animals were anaesthetized with diethyl ether, and placed in a heparinized tube for subsequent ${ }^{55} \mathrm{Fe}$ and ${ }^{59} \mathrm{Fe}$ measurement. Blood volume was calculated assuming it to be $7 \cdot 2 \%$ body-weight (Metcoff \& Favour, 1944). Packed cell volume was measured and the liver, heart, kidneys and spleen were removed and the ${ }^{59} \mathrm{Fe}$ content directly measured in a gamma-counter.

\section{In vitro iron availability measurements}

Gastric juice was collected from a human subject on several occasions after an overnight fast. The subject swallowed a Ryles tube (size $10 \mathrm{FG}$ ) and then drank 0.51 distilled water. After 15-20 min the gastric contents were removed with the aid of a syringe and filtered through Whatman 41 filter paper into a plastic bottle. Samples were stored frozen and bulked before carrying out the in vitro measurements. The $\mathrm{pH}$ was adjusted to 2.0 with dilute $\mathrm{HCl}$ and the pepsin activity measured.

A series of foods was prepared as for human consumption and oven-dried at $50^{\circ}$. They were ground to pass through a $300 \mu \mathrm{m}$ nylon sieve and $0.5 \mathrm{~g}$ samples were incubated in plastic tubes at $37^{\circ}$ for $1.5 \mathrm{~h}$ with $5 \mathrm{ml}$ gastric juice. The tubes were centrifuged and the supernatant fraction analysed for Fe by atomic absorption spectrophotometry (AAS). The foods were analysed for total Fe by AAS. The Fe solubility in gastric juice of a number of samples of instant potato, some of which had been fortified with ascorbic acid during manufacture, was also measured together with the ascorbic acid level.

\section{Analytical methods}

Ascorbic acid. This was measured by extraction from the food with metaphosphoric acid followed by titration against 2,6-dichlorophenol indophenol (Horwitz, 1975).

Pepsin. The peptic activity was assayed by measurement of the concentration of peptides released from a haemoglobin substrate when incubated for a fixed time with gastric juice (Anson, 1938). One unit of activity is equivalent to the absorbance resulting from reaction of the reagent with $0.001 \mathrm{M}$-tyrosine.

$\mathrm{Fe}$. Dried samples were ashed at $480^{\circ}$ in silica crucibles for $48 \mathrm{~h}$, the ash taken up in warm, concentrated $\mathrm{HCl}$, the solution filtered and analysed by flame spectrophotometry on a Varian AA6 AAS with background correction. Solutions of supernatant fraction from the in vitro gastric juice incubation were analysed directly using appropriate standards.

Radioactivity. The ${ }^{59} \mathrm{Fe}$ content of faeces and organs was measured in a Philips PW4580 Automatic Gamma Counter with a $75 \times 75 \mathrm{~mm}$ sodium iodide crystal, centre 535, width 30 , gauge 20 .

Liquid-scintillation counting. Portions of $0.1 \mathrm{ml}$ heparinized blood were counted by a modification of the dual-label technique of Eakins \& Brown (1966). The samples were digested with $1.5 \mathrm{ml}$ Soluene 350 (Packard Instruments, Berks.) propan-2-ol $(1: 1, \mathrm{v} / \mathrm{v})$ for $12 \mathrm{~h}$ and then $0.5 \mathrm{ml}$ hydrogen peroxide $(300 \mathrm{~g} / \mathrm{l})$ added and left to stand for $3 \mathrm{~h}$. Finally $15 \mathrm{ml}$ Instagel (Packard)-0.5- $\mathrm{M}-\mathrm{HCl}(9: 1, \mathrm{v} / \mathrm{v})$ was added and the vials counted in a Philips liquid-scintillation counter. The settings used were channel 1: attentuation 3.9, 40-1000; channel 2: attenuation 3.9, 40-120; channel 3: attenuation $0 \cdot 0,40-400$. The channels ratio method of standardization was used for the preparation of quench curves and counting efficiencies were $84 \%$ for ${ }^{59} \mathrm{Fe}$ and $19 \%$ for ${ }^{55} \mathrm{Fe}$. 
Table 1. Iron intakes and excretion $(\mathrm{mg} / 10 \mathrm{~d})$ of rats given either a diet containing $660 \mathrm{~g}$ potato $/ \mathrm{kg}$ or a semi-synthetic diet containing ferrous sulphate*

(Mean values with their standard errors for eight animals on the potato diet and ten animals on the control- $\mathrm{FeSO}_{4}$ diet)

\begin{tabular}{lccccccc}
\hline & Potato diet $\dagger$ & & $\begin{array}{c}\text { Control- } \\
\text { FeSO }\end{array}$ & & $\begin{array}{c}\text { Statistical } \\
\text { significance } \\
\text { of difference } \\
\text { between groups }\end{array}$ \\
& Mean & SE & Mean & SE & NS \\
Fe intake & 1.64 & 0.07 & 1.60 & 0.05 & \\
Fe excretion & 1.38 & 0.05 & 1.09 & 0.05 & $P<0.001$ \\
Fe absorbed & 0.26 & 0.05 & 0.51 & 0.05 & $P<0.002$ \\
Percentage absorption & 15.2 & 2.7 & 32.1 & 2.8 & $P<0.001$ \\
\hline
\end{tabular}

NS, not significant.

* For details, see p. 16.

$\uparrow$ Two animals were excluded from the experiment because of respiratory illness.

Table 2. Iron absorption from extrinsically-labelled potato and ferrous sulphate

(Mean values with their standard errors for thirteen animals in each group)

\begin{tabular}{|c|c|c|c|c|c|c|}
\hline \multirow[t]{2}{*}{ Source of Fe... } & \multirow[b]{2}{*}{ Fe label } & \multicolumn{2}{|c|}{ Potato } & \multicolumn{2}{|c|}{$\mathrm{FeSO}_{4}$} & \multirow{2}{*}{$\begin{array}{c}\text { Statistical } \\
\text { significance } \\
\text { of difference } \\
\text { between groups }\end{array}$} \\
\hline & & Mean & SE & Mean & SE & \\
\hline \multirow{3}{*}{$\begin{array}{l}\text { Faecal excretion } \\
(\% \text { of dose }) \\
\text { Blood content } \\
(\% \text { of dose })\end{array}$} & ${ }^{59} \mathrm{Fe}$ & $50 \cdot 4$ & $1 \cdot 1$ & 37.6 & $1 \cdot 2$ & $P<0.001$ \\
\hline & ${ }^{58} \mathrm{Fe}$ & $40 \cdot 4$ & $1 \cdot 4$ & $49 \cdot 1$ & $2 \cdot 0$ & $P<0.001$ \\
\hline & ${ }^{55} \mathrm{Fe}$ & $45 \cdot 3$ & $2 \cdot 1$ & $49 \cdot 3$ & 1.7 & NS \\
\hline
\end{tabular}

NS, not significant.

* Blood volume estimated as $7 \cdot 2 \%$ body-weight (Metcoff \& Favour, 1944).

\section{Statistical analysis}

Where appropriate unpaired $t$ tests were performed to see if there was a significant difference between groups (Snedecor \& Cochran, 1967). Paired $t$ tests were carried out on the values for ${ }^{59} \mathrm{Fe}$ and ${ }^{55} \mathrm{Fe}$ content of blood in the radioisotope experiment. The Spearman rank correlation coefficient was calculated for the in vitro experiment measuring Fe solubilization from potatoes (Siegel, (1956).

\section{RESULTS}

\section{Balance experiment}

The Fe content of the control semi-synthetic diet was $15.2 \mu \mathrm{g} / \mathrm{g}$ and of the potato diet was $17.4 \mu \mathrm{g} / \mathrm{g}$. Fe balance values for the $10 \mathrm{~d}$ period, shown in Table 1 , indicate that the $\mathrm{Fe}$ from potatoes was about half as available as the well-absorbed $\mathrm{FeSO}_{4}$. There were no significant differences in weight gain or food intakes between the groups although the potato group ate slightly less $(9.4 \mathrm{~g} / \mathrm{d} \mathrm{v} .10 .7 \mathrm{~g} / \mathrm{d}$ in the controls). Ascorbic acid analysis showed that the cooked, freeze-dried potato powder had lost most of its ascorbic acid. Immediately after freeze-drying the concentration of ascorbic acid was $67 \mathrm{mg} / \mathrm{kg}$ dried potato and it may 


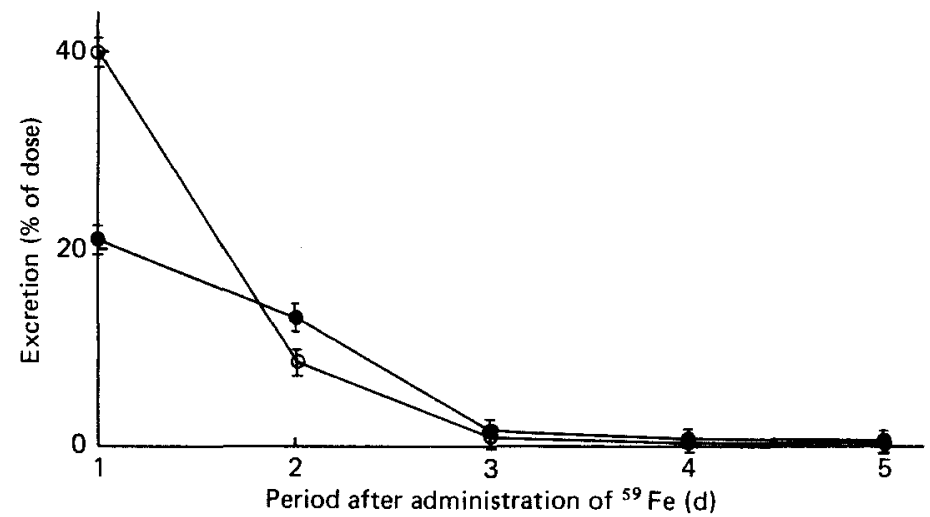

Fig. 1. Daily faecal excretion of ${ }^{59} \mathrm{Fe}$ by rats given ${ }^{59} \mathrm{Fe}$-labelled potato $(O)$ or ${ }^{59} \mathrm{Fe}$-labelled ferrous sulphate (O). Points are mean values with their standard errors represented by vertical bars.

Table $3 .{ }^{59} \mathrm{Fe}$ content of organs $(\%$ of dose) of rats given extrinsically-labelled potato and ferrous sulphate

(Mean values with their standard errors for thirteen animals in each group)

\begin{tabular}{|c|c|c|c|c|c|}
\hline \multirow[t]{2}{*}{$\begin{array}{c}\text { Group... } \\
\text { Source of Fe... }\end{array}$} & \multicolumn{2}{|c|}{$\begin{array}{c}1 \\
{ }^{59} \mathrm{Fe}-\text { labelled } \\
\text { potato }\end{array}$} & \multicolumn{2}{|c|}{$\begin{array}{c}2 \\
{ }^{59} \mathrm{FeSO}_{4}\end{array}$} & \multirow{2}{*}{$\begin{array}{c}\text { Statistical } \\
\text { significance } \\
\text { of difference } \\
\text { between groups }\end{array}$} \\
\hline & Mean & $\mathrm{SE}$ & Mean & $\mathbf{S E}$ & \\
\hline Liver & 1.61 & $0 \cdot 10$ & $2 \cdot 35$ & $0 \cdot 14$ & $P<0.001$ \\
\hline Heart & $0 \cdot 27$ & 0.02 & $0 \cdot 30$ & 0.01 & NS \\
\hline Kidneys & 0.55 & 0.02 & 0.58 & 0.05 & NS \\
\hline Spleen & 0.35 & 0.02 & 0.38 & 0.01 & NS \\
\hline
\end{tabular}

NS, not significant.

well have fallen further on storage. Fresh potatoes contain $80-200 \mathrm{mg}$ ascorbic acid $/ \mathrm{kg}$ wet weight which is equivalent to $400-1000 \mathrm{mg}$ ascorbic acid $/ \mathrm{kg}$ dried potato, i.e. ten times that of the freeze-dried potato.

\section{Radioisotope experiment}

The dried potato contained $19.7 \mu \mathrm{g} \mathrm{Fe} / \mathrm{g}$, thus the $3 \mathrm{~g}$ meal contained $59 \cdot 1 \mu \mathrm{g} \mathrm{Fe}$. Absorption from $\mathrm{FeSO}_{4}(52 \mu \mathrm{g} \mathrm{Fe})$ in a starch-sucrose paste was compared with that from potato and the results are shown in Table 2 . Fe absorption calculated from faecal excretion was significantly higher $(P<0.001)$ from $\mathrm{FeSO}_{4}(62 \cdot 4 \%)$ than potato $(49 \cdot 6 \%) .{ }^{5 \%} \mathrm{Fe}$ faecal excretion was more rapid after the potato meal than the ${ }^{59} \mathrm{FeSO}_{4}$ in starch-sucrose paste, as shown in Fig. 1, probably because of the higher fibre content of the potato. Excretion had fallen to less than $1 \%$ of the administered dose after $3 \mathrm{~d}$. Analysis of the blood showed a significantly higher content of ${ }^{55} \mathrm{Fe}$ from $\mathrm{FeSO}_{4}$ than from ${ }^{59} \mathrm{Fe}$-labelled potato. There was, however, no significant difference between ${ }^{59} \mathrm{FeSO}_{4}$ and ${ }^{55} \mathrm{Fe}$-labelled potato. The ${ }^{59} \mathrm{Fe}$ content of the organs is shown in Table 3 . The ${ }^{59} \mathrm{Fe}$ content of the liver was significantly higher in the ${ }^{59} \mathrm{FeSO}_{4}$ group. There was no difference in blood packed cell volume between the two groups: packed cell volume (mean with SE) was $44 \cdot 1(0.8)$ in group 1 and $43.4(0.5)$ in group 2. 
Table 4. Iron content and amount of Fe solubilized by gastric juice in a range of foodstuffs (Mean values with their standard errors)

\begin{tabular}{|c|c|c|c|c|}
\hline \multirow[b]{3}{*}{ Food (and source) } & \multirow{3}{*}{$\begin{array}{l}\text { Total Fe } \\
(\mu \mathrm{g} / \mathrm{g})\end{array}$} & \multicolumn{3}{|c|}{$\begin{array}{l}\text { Fe solubilized in } \\
\text { gastric juice }\end{array}$} \\
\hline & & \multicolumn{2}{|c|}{$\mu \mathrm{g} / \mathrm{g}$} & \multirow{2}{*}{$\begin{array}{c}\% \\
\text { of total }\end{array}$} \\
\hline & & Mean & $\mathrm{SE}$ & \\
\hline All-Bran ${ }^{\circledR}$ (Kellogg's) & $129 \cdot 1$ & $17 \cdot 4$ & 0.6 & $13 \cdot 5$ \\
\hline Bran (Prewett's) & 121.8 & $23 \cdot 9$ & $0 \cdot 8$ & $19 \cdot 7$ \\
\hline $\begin{array}{l}\text { Kidney beans (canned red } \\
\text { Californian beans) }\end{array}$ & $64 \cdot 3$ & $6 \cdot 7$ & $0 \cdot 3$ & $10 \cdot 5$ \\
\hline Baked beans (Heinz) & $48 \cdot 9$ & 5.9 & $0 \cdot 3$ & $12 \cdot 1$ \\
\hline Wholemeal flour (Prewett's) & $46 \cdot 5$ & $5 \cdot 2$ & $0 \cdot 3$ & $11 \cdot 1$ \\
\hline $\begin{array}{l}\text { Wholemeal bread } \\
\text { (Sainsbury's) }\end{array}$ & $41 \cdot 2$ & $2 \cdot 8$ & 0.2 & 6.8 \\
\hline Wholemeal flour (Jordan's) & $39 \cdot 0$ & $5 \cdot 1$ & $0 \cdot 1$ & $13 \cdot 1$ \\
\hline $\begin{array}{l}\text { White flour (Sainsbury's } \\
\text { plain home-milled) }\end{array}$ & $21 \cdot 4$ & $3 \cdot 4$ & 0.2 & $16 \cdot 1$ \\
\hline White bread (Sainbury's) & $20 \cdot 1$ & $1 \cdot 2$ & $0 \cdot 1$ & $6 \cdot 1$ \\
\hline Dried Maris Piper potato & $19 \cdot 7$ & 8.7 & 0.5 & $44 \cdot 3$ \\
\hline $\begin{array}{l}\text { Instant potato } \\
\left.\text { (Cadbury's Smash }^{\$}\right)\end{array}$ & $19 \cdot 1$ & $12 \cdot 9$ & $0 \cdot 3$ & 67.5 \\
\hline
\end{tabular}

\section{In vitro Fe availability measurements}

The bulked gastric juice had a $\mathrm{pH}$ of $2 \cdot 2$, which was standardized to $2 \cdot 0$ with $\mathrm{HCl}$, and a pepsin activity equivalent to a solution of pepsin containing $260 \mathrm{mg} / \mathrm{l}$. The $\mathrm{Fe}$ content and amount of $\mathrm{Fe}$ solubilized by gastric juice in a range of foodstuffs (mean of at least four separate duplicate determinations) are shown in Table 4. Although the Fe content of instant and laboratory-dried potato was lowest, the $\mathrm{Fe}$ solubility when expressed as a percentage of total $\mathrm{Fe}$ was highest, notably from the instant potato with added ascorbic acid.

The ascorbic acid content of potato samples and Fe solubilization is shown in Table 5. The different levels of ascorbic acid were related to time of storage, most of the samples having originally been fortified with ascorbic acid. There was a significant correlation between ascorbic acid content and amount of Fe solubilized in gastric juice $\left(r_{s} 0 \cdot 76\right.$, $P<0.01$ ).

Ascorbic acid was added to some of the other foods and at a level of $20 \mathrm{mg} / \mathrm{g}$ dried food it increased $\mathrm{Fe}$ solubilization from bran by a factor of 0.5 , from baked beans by 1.3 and from wholemeal flour by $3 \cdot 1$. It only increased Fe solubilization from instant potato by a factor of $0 \cdot 15$, which is not surprising since the potato already contained significant amounts of ascorbic acid.

\section{DISCUSSION}

It is difficult to compare results from different studies measuring $\mathrm{Fe}$ availability in foods or meals. It is well-known that $\mathrm{Fe}$ absorption varies widely between different individuals, depending, for example, on their Fe status and there are also day-to-day variations in the same individual. Wherever possible, it is common practice to standardize the results by comparing Fe availability from a food with that from a well-absorbed Fe salt such as ferrous sulphate. This value gives some indication of the extent of availability of the food $\mathrm{Fe}$. The second problem with $\mathrm{Fe}$ availability studies is in the interpretation of results, i.e. making 
Table 5. Ascorbic acid content of potatoes and iron solubilization

\begin{tabular}{cc}
\hline \hline $\begin{array}{c}\text { Ascorbic acid } \\
(\mathrm{mg} / \mathrm{kg})\end{array}$ & $\begin{array}{c}\text { Fe solubilized in } \\
\text { gastric juice } \\
(\mu \mathrm{g} / \mathrm{g} \text { potato })\end{array}$ \\
\hline 820 & $12 \cdot 7$ \\
770 & $12 \cdot 7$ \\
740 & $12 \cdot 7$ \\
730 & $12 \cdot 4$ \\
160 & $10 \cdot 1$ \\
105 & $11 \cdot 2$ \\
100 & $11 \cdot 7$ \\
75 & $10 \cdot 2$ \\
67 & $8 \cdot 7$ \\
50 & $8 \cdot 2$ \\
45 & $11 \cdot 4$ \\
35 & $9 \cdot 9$ \\
\hline
\end{tabular}

Spearman, $r_{s} 0 \cdot 76, P<0 \cdot 01$.

allowances for differing Fe requirements. Thus Fe-deficient individuals will absorb more Fe than normal individuals (Brise, 1962). Similarly, growing rats appear to absorb more $\mathrm{Fe}$ than adult rats, presumably because their requirements are greater. Therefore, it can be misleading to compare figures for Fe absorption in the rat and man directly, although Schricker et al. (1981) have demonstrated a correlation between human and rat in vivo studies of $\mathrm{Fe}$ availability. When human studies are not possible, the best way of estimating non-haem-Fe availability in foods is a rat in vivo study comparing the food $\mathrm{Fe}$ with $\mathrm{FeSO}_{4}$ coupled with in vitro studies of availability, as discussed later.

The experiments with rats indicate that the $\mathrm{Fe}$ in potatoes is at least half as available as that of the well-absorbed salt $\mathrm{FeSO}_{4}$, even though $90 \%$ of the potatoes' ascorbic acid had been lost in the preparation. Rats given a single meal of ${ }^{59} \mathrm{Fe}$ extrinsically-labelled potato absorbed $50 \%$ of the $\mathrm{Fe}$ compared with $62 \%$ of $\mathrm{Fe}$ from ${ }^{59} \mathrm{FeSO}_{4}$. Because of the difficulties of measuring ${ }^{55} \mathrm{Fe}$ in faeces it was not possible to compare $\mathrm{Fe}$ absorption from $\mathrm{FeSO}_{4}$ and potatoes in the same animals using the technique of faecal monitoring.

Since most of the absorbed $\mathrm{Fe}$ was incorporated into the blood by the end of $12 \mathrm{~d}$, with only a small amount in the liver, the blood content is a useful indicator of $\mathrm{Fe}$ absorption However, blood volume cannot be measured accurately and the values for ${ }^{55} \mathrm{Fe}$ and ${ }^{59} \mathrm{Fe}$ content of the blood shown in Table 2 are merely an indication of total amounts circulating in the blood. It is clear that there was little difference in $\mathrm{Fe}$ absorption from $\mathrm{FeSO}_{4}$ and potato; paired $t$ tests showed a significant difference in one group but not in the other. It can be concluded that $\mathrm{Fe}$ availability was marginally higher from $\mathrm{FeSO}_{4}$ than potato.

The $10 \mathrm{~d}$ balance study in which the rats were fed $a d$ lib. a diet where potato was the main source of $\mathrm{Fe}$ or a diet comparable in protein, energy and $\mathrm{Fe}$ content in which $\mathrm{FeSO}_{4}$ was the main source of $\mathrm{Fe}$, showed that the potato $\mathrm{Fe}$ was about half as available as $\mathrm{FeSO}_{4}$. Absorption was $32 \%$ from $\mathrm{FeSO}_{4}$ and $15 \%$ from potato which is lower than from single meals, even though the animals were of a similar age. This is not an unexpected finding since it has been shown that Fe absorption is increased on fasting (Brise, 1962).

The availability of $\mathrm{Fe}$ in potatoes compares well with that of $\mathrm{Fe}$ naturally present in bread. Previous work (Fairweather-Tait, 1982) has shown that the absorption from wholemeal bread by weanling rats on a $14 \mathrm{~d}$ balance study was half that from $\mathrm{FeSO}_{4}$. When the animals were given a single-labelled meal absorption was greater, as was found with the potato study, 
and the wheat: $\mathrm{FeSO}_{4}$ value was 0.77. Mahoney et al. (1974) showed that the efficiency of converting wheat $\mathrm{Fe}$ into haem-Fe in young, anaemic rats was two-thirds that of ferrous ascorbate. These results using rats compare well with results from normal human subjects in which Fe absorption from intrinsically-labelled wheat was two-thirds that from ferrous ascorbate (Hussain et al. 1965). There was an inevitable loss of ascorbic acid when the cooked, dried potato was prepared for the animal experiments. Ascorbic acid enhances non-haem-Fe absorption because it is not only a powerful reducing agent but also binds $\mathrm{Fe}$ in equimolar concentrations. The promoting effect of ascorbic acid has been shown to be dose-dependent (Sayers et al. 1973). When ascorbic acid is added to the diet the increase in $\mathrm{Fe}$ absorption above the basal level follows a log-linear relationship (Bothwell et al. 1979), but there is a minimum level which must be reached before the $\mathrm{Fe}$ absorption is affected. Thus Sayers et al. (1974) found that, whereas $60 \mathrm{mg}$ ascorbic acid added to a rice meal containing $4 \mathrm{mg} \mathrm{Fe}$ as $\mathrm{FeSO}_{4}$ significantly increased $\mathrm{Fe}$ absorption in adult subjects, $35 \mathrm{mg}$ was not enough to improve $\mathrm{Fe}$ availability. This threshold effect possibly indicates two types of action of ascorbic acid on $\mathrm{Fe}$, one being the reduction of ferric to ferrous ions and the other the formation of an ascorbic acid-Fe chelate. An average helping of $150 \mathrm{~g}$ boiled potato would provide $5-20 \mathrm{mg}$ ascorbic acid, which on its own would probably not be enough to influence Fe absorption significantly. However, when other sources of ascorbic acid are consumed at the same meal, such as another vegetable or some fruit, the amount of ascorbic acid might be enough to increase $\mathrm{Fe}$ absorption from the whole meal.

It has been suggested that Fe solubilization is the initial determinant of Fe availability from a food or meal and a variety of in vitro methods have been proposed to measure $\mathrm{Fe}$ availability. To be absorbed the $\mathrm{Fe}$ must first be ionized and this is only possible with $\mathrm{Fe}$ in solution. Thus it is likely that a measure of high solubilization indicates an Fe source of potentially-high availability. Miller et al. (1981) used an in vitro technique to estimate Fe availability from meals in which the homogenized foods were subjected to simulated digestion. They were incubated at $37^{\circ}$ for $2 \mathrm{~h}$ in a pepsin- $\mathrm{HCl}$ mixture $(5 \mathrm{~g}$ pepsin $/ \mathrm{kg}$ meal) at $\mathrm{pH} 2 \cdot 0$. Dialysis was then used to adjust the $\mathrm{pH}$ to intestinal levels and the digestion was continued after the addition of pancreatin and bile salts. They tested the effect of adding enhancing or inhibiting factors on $\mathrm{Fe}$ availability and found the results very promising. They then went on to compare in vivo and in vitro methods for determining the availability of $\mathrm{Fe}$ in meals (Schricker et al. 1981). They found substantial agreement between the in vitro and human in vivo methods. However, because the meals they used contained meat the correlations between rat in vivo and human in vitro results were less significant although, possibly surprisingly, there was a reasonable corrleation between the rat in vivo and human in vivo results. Using a simpler system, as described in the present study, Lock \& Bender (1980) showed a reasonable correlation in a range of foods between Fe solubilization in gastric juice and in vivo availability.

The in vitro results in Table 4 show that a much higher proportion of $\mathrm{Fe}$ was solubilized in gastric juice from fortified or unfortified potato than any of the other foods tested. The two vegetables, kidney beans and baked beans had 10.5 and $12.1 \%$ of total $\mathrm{Fe}$ solubilized whereas dried main-crop potato had $44.3 \%$ and instant potato (fortified with ascorbic acid) had $67.5 \%$ of total $\mathrm{Fe}$ solubilized. As shown in Table 5, Fe solubilization in potato samples was correlated with ascorbic acid content $\left(r_{s} 0.76, P<0.01\right)$ despite the fact that the potato samples were of different origins and possibly of different composition. Other work (S. J. Fairweather-Tait, unpublished results) has shown that there was a closer correlation between Fe solubilization from a single food and added ascorbic acid (which followed a log-linear relationship) since the Fe content and chemical composition of the food remained constant, unlike the samples of potato. Despite the fact that most of the ascorbic acid had been removed in drying the main-crop potato a high proportion of $\mathrm{Fe}$ was solubilized in 
gastric juice although the proportion of Fe solubilized from instant potato which had been fortified with ascorbic acid was in fact greater.

Most vegetables are considered to be a poor source of $\mathrm{Fe}$, despite reasonably high $\mathrm{Fe}$ levels, because the $\mathrm{Fe}$ is poorly absorbed. According to Layrisse \& Martinez-Torres (1971), $1-7 \%$ of the $\mathrm{Fe}$ in vegetable staples such as rice, maize, black beans, soya beans and wheat are absorbed if they are consumed as single items, the $\mathrm{Fe}$ in wheat and soya beans being the most available. The rat studies described in this paper show the $\mathrm{Fe}$ in potatoes to be as well absorbed or better absorbed than wheat Fe. This evidence alone suggests that potatoes contain Fe of moderate availability. The in vitro studies show a distinct difference in solubilization between potatoes and other foods, such as beans, which suggests superior availability. Account must be taken of the fact that there was an inevitable loss of most of the ascorbic acid in the preparation of the potato samples; potatoes as normally eaten will contain at least five times more ascorbic acid. Thus, when eaten with other foods the ascorbic acid will contribute towards the total in the meal and if this reaches a high enough level it will enhance non-haem-Fe absorption from the meal. Therefore, potatoes may make a useful contribution towards the Fe nutriture of the UK population.

The author thanks Ms Viv Simmonds for her assistance with the animals, Mrs Wendy Nelson for technical help, Mr M. Gee for the AAS analyses, Dr D. P. Richardson of Cadbury-Schweppes for the samples of instant potato and Dr D. A. T. Southgate for advice in the preparation of this paper.

\section{REFERENCES}

Amine, E. K. \& Hegsted, D. M. (1971). Journal of Nutrition 101, 927-936.

Anson, M. L. (1938). Journal of General Physiology 22, 79-89.

Bothwell, T. H., Charlton, R. W., Cook, J. D. \& Finch, C. A. (1979). Iron Metabolism in Man. Oxford: Blackwell. Brise, H. (1962). Acta Medica Scandinavica Supplementum 376 59, 39-45.

Eakins, J. D. \& Brown, D. A. (1966). International Journal of Applied Radiation and Isotopes 17, $391-397$.

Fairweather-Tait, S. J. (1982). British Journal of Nutrition 47, 243-249.

Fritz, J. C., Pla, G. W., Harrison, B. N. \& Clark, G. A. (1974). Journal of the Association of Official Analytical Chemists 57, 513-516.

Horwitz, W. (editor) (1975). Official Methods of Analysis of the Association of Official Analytical Chemists, p. 829. Washington DC: Association of Official Analytical Chemists.

Hussain, R., Walker, R. B., Layrisse, M., Clark, P. \& Finch, C. A. (1965). American Journal of Clinical Nutrition 16, $464-471$.

Layrisse, M., Cook, J. D., Martinez, C., Roche, M., Kuhn, I. N., Walker, R. B. \& Finch, C. A. (1969). Blood 33, 430-443.

Layrisse, M. \& Martinez-Torres, C. (1971). Progress in Hematology 7, 137-160.

Lock, S. \& Bender, A. E. (1980). British Journal of Nutrition 43, 413-420.

Mahoney, A. W., Van Orden, C. C. \& Hendricks, D. G. (1974). Nutrition and Metabolism 17, 223-230.

Metcoff, J. \& Favour, C. B. (1944). American Journal of Physiology 141, 695-706.

Miller, D. D., Schricker, B. R., Rasmussen, R. R. \& Van Campen, D. (1981). American Journal of Clinical Nutrition 34, 2248-2256.

Ministry of Agriculture, Fisheries and Food (1980). Household Food Consumption and Expenditure. London: HM Stationery Office.

Paul, A. A. \& Southgate, D. A. T. (1978). McCance \& Widdowson's The Composition of Foods, London: HM Stationery Office.

Sayers, M. H., Lynch, S. R., Charlton, R. W., Bothwell, T. H., Walker, R. B. \& Mayet, F. (1974). British Journal of Nutrition 31, 367-375.

Sayers, M. H., Lynch, S. R., Jacobs, P., Charlton, R. W., Bothwell, T. H., Walker, R. B. \& Mayet, F. (1973). British Journal of Haematology 24, 209-218.

Schricker, B. R., Miller, D. D., Rasmussen, R. R. \& Van Campen, D. (1981). American Journal of Clinical Nutrition 34, 2257-2263.

Siegel, S. (1956). Nonparametric Statistics for the Behavioural Sciences. Kogakusha: McGraw-Hill.

Snedecor, G. W. \& Cochran, W. G. (1967). Statistical Methods, 6th ed. Ames, Iowa: Iowa State University Press. 